\title{
IgE-Mediated Food Allergy
}

\author{
Sara Anvari ${ }^{1} \cdot$ Jennifer Miller ${ }^{1} \cdot$ Chih-Yin Yeh ${ }^{1} \cdot$ Carla M. Davis $^{1}$ (1)
}

Published online: 29 October 2018

(C) The Author(s) 2018

\begin{abstract}
Food allergies are defined as adverse immune responses to food proteins that result in typical clinical symptoms involving the dermatologic, respiratory, gastrointestinal, cardiovascular, and/or neurologic systems. IgE-mediated food-allergic disease differs from non-IgE-mediated disease because the pathophysiology results from activation of the immune system, causing a T helper 2 response which results in IgE binding to $F_{c} \varepsilon$ receptors on effector cells like mast cells and basophils. The activation of these cells causes release of histamine and other preformed mediators, and rapid symptom onset, in contrast with non-IgE-mediated food allergy which is more delayed in onset. The diagnosis of IgE-mediated food allergy requires a history of classic clinical symptoms and evidence of food-specific IgE by either skin-prick or serum-specific IgE testing. Symptoms of IgE-mediated food allergies range from mild to severe. The severity of symptoms is not predicted by the level of specific IgE or skin test wheal size, but the likelihood of symptom onset is directly related. Diagnosis is excluded when a patient can ingest the suspected food without clinical symptoms and may require an in-office oral food challenge if testing for food-specific IgE by serum or skin testing is negative or low. Anaphylaxis is the most severe form of the clinical manifestation of IgE-mediated food allergy, and injectable epinephrine is the first-line treatment. Management of food allergies requires strict avoidance measures, counseling of the family about constant vigilance, and prompt treatment of allergic reactions with emergency medications. Guidelines have changed recently to include early introduction of peanuts at 4-6 months of life. Early introduction is recommended to prevent the development of peanut allergy. Future treatments for IgE-mediated food allergy evaluated in clinical trials include epicutaneous, sublingual, and oral immunotherapy.
\end{abstract}

Keywords Food allergy $\cdot \operatorname{IgE} \cdot$ Mast cell $\cdot$ Tolerance $\cdot$ Sensitization $\cdot$ Anaphylaxis $\cdot$ Pathophysiology $\cdot$ Food allergy diagnosis Treatment of food allergy $\cdot$ Food immunotherapy

\section{Introduction}

Food allergies, defined as adverse immune responses to food proteins, are becoming increasingly common conditions. Food allergy is very distinct from food intolerance, which is defined as a non-immune reaction that includes metabolic, toxic, pharmacologic, and undefined mechanisms [1]. Food allergy is not one disease but a spectrum of clinicopathological disorders [2]. Diseases associated with immune-mediated food allergy include acute urticaria/angioedema, oral allergy syndrome, atopic dermatitis, eosinophilic gastrointestinal

Carla M. Davis

carlad@bcm.edu

1 Section of Immunology, Allergy and Rheumatology, Baylor College of Medicine, Texas Children's Hospital, 1102 Bates Avenue, MC 330.01, Houston, TX 77030, USA disease, allergic contact dermatitis, and food protein-induced enteropathy/enterocolitis syndrome. Although celiac disease is an immune-mediated disease triggered by gluten, a food protein, it is not typically classified as a food-allergic disease. As such, manifestations of food allergies differ significantly, depending on the immune mechanism involved and the affected target organ, ranging from the prototypical acute urticaria/ angioedema to more chronic conditions such as eczema or eosinophilic gastrointestinal disease (Fig. 1). Diagnostic tools for food allergies must be used in the context of the clinical symptoms for accurate disease assessment (Fig. 2).

Food allergies can be grouped in two general categories: IgE-mediated and non-IgE-mediated [1]. IgE-mediated reactions are typically of rapid onset with clinical symptoms usually developing within minutes to a few hours of ingestion. NonIgE-mediated disease is typically chronic and may be more difficult than IgE-mediated disease to control with food avoidance alone. IgE-mediated food-allergic disease is associated with fatal anaphylaxis, especially with peanut, tree nuts, and 


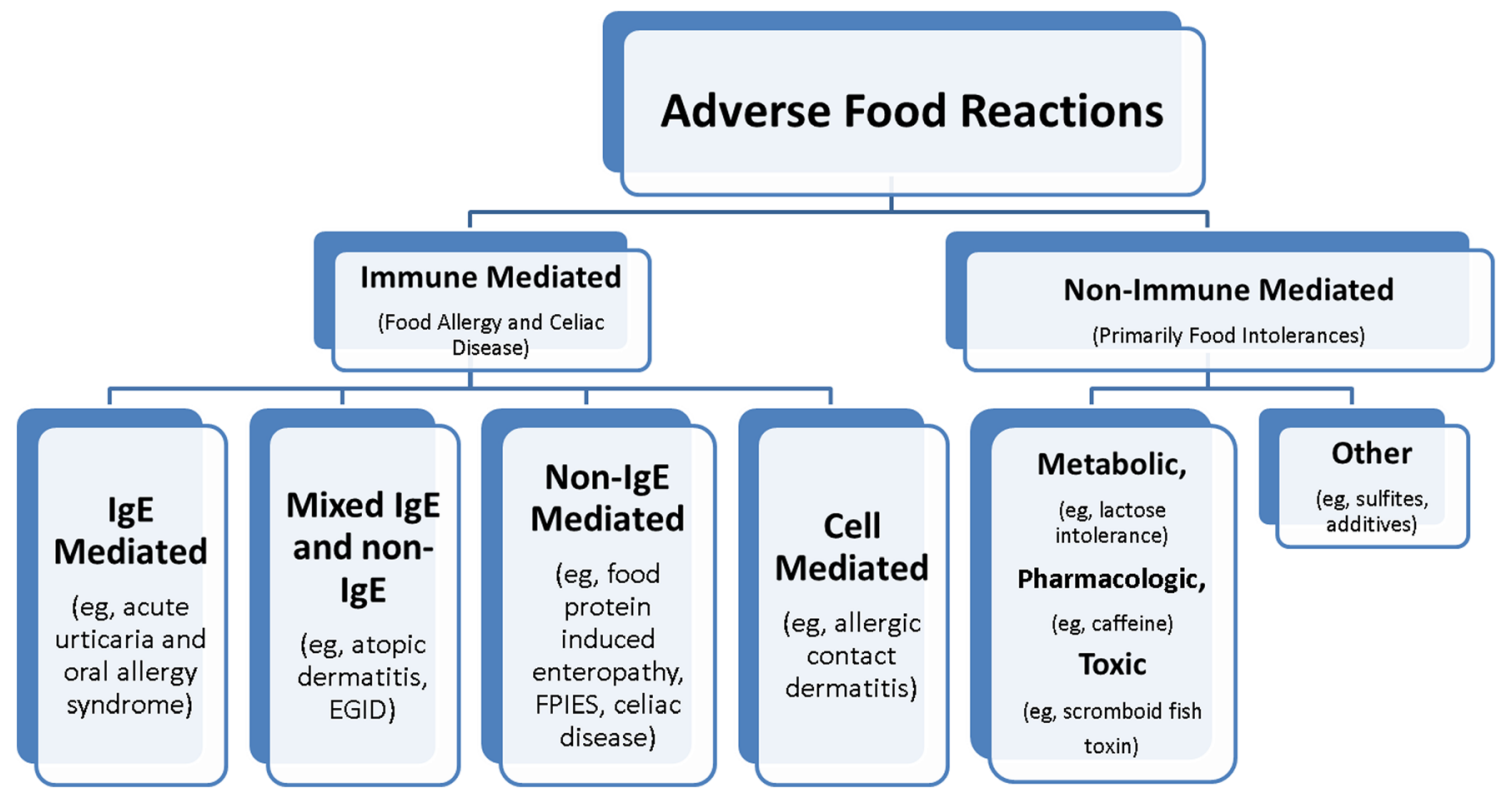

Fig. 1 Classification of adverse reactions to food (adapted from Sampson et al. [2])

seafood. The potential for this devastating outcome and the widespread media coverage of this epidemic has resulted in increased awareness of food allergies and fear for those affected. More people believe they have food allergies than prevalence estimates show based on physician diagnosis. Up to one third of the population believes they have a food allergy, but the prevalence is $5 \%$ of adults and $8 \%$ of children [2]. The prevalence has been increasing over the past decade, causing this to

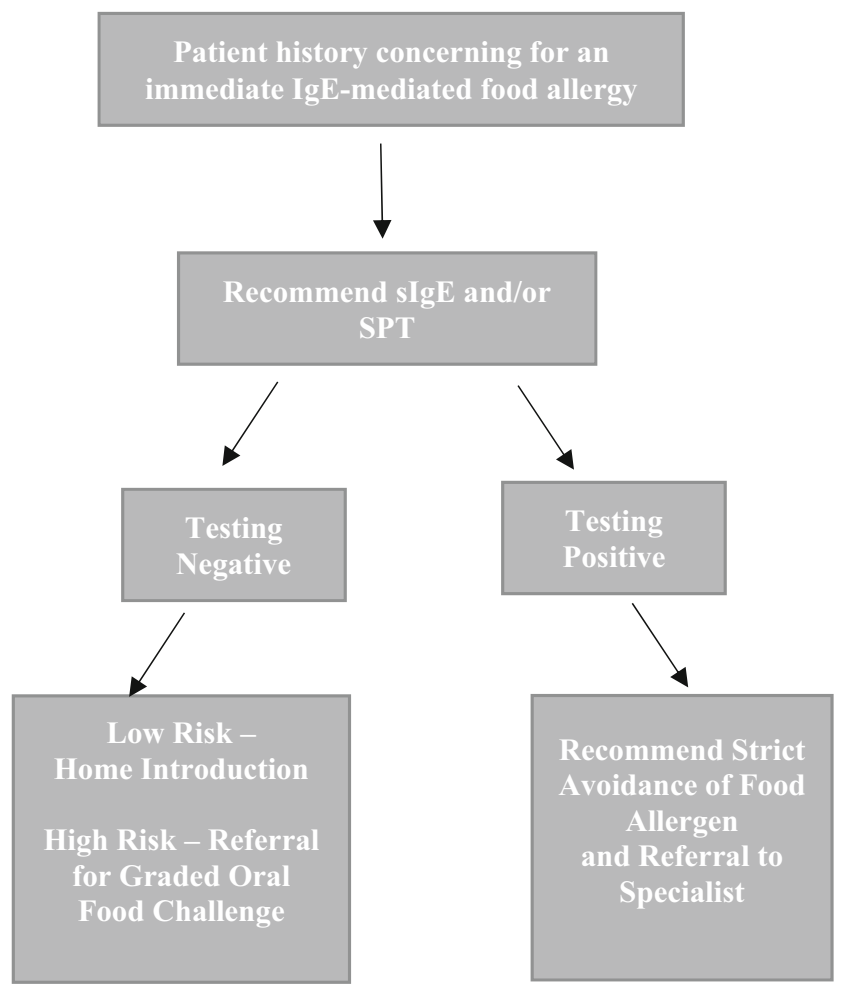

Fig. 2 Diagnostic algorithm for food allergy diagnosis be an important public health issue. Physician awareness of the limitations of clinical history alone in diagnostic accuracy for food allergies and judicious use of testing will help decrease false diagnoses. This review article will address the pathophysiology, clinical manifestations, diagnostic approaches, and management of IgE-mediated food allergies.

\section{Pathophysiology}

The immune system plays an integral role in the maintenance of tolerance to innocuous antigens. IgE-mediated food allergies occur as a result of a loss of integrity in the key immune components that maintain a state of tolerance and prevent benign food antigens from being recognized as pathogens. More specifically, oral tolerance to foods is defined as the crossing of food antigen across the mucosal barrier, processing by dendritic cells in a non-activated state, and the induction of suppressive cytokines, such as interleukin 10, by those antigen-presenting cells. This in turn results in the differentiation of naïve $T$ cells into $T$ regulatory cells and suppression of food antigen-specific Th2 cells, as well as increased IgA and IgG4 production and a decrease in IgE by B cells. Finally, there is immune suppression of eosinophils, basophils, and mast cells, effector cells which cause symptoms.

Sensitization is defined as the state of having detectable food-specific IgE which can be a precursor to the development of clinical food allergy. It occurs when food crosses disrupted barrier and as a result of this disruption, danger signals and inflammatory cytokines are released which activate dendritic cells into phenotypes that are normally acquired during the defense against pathogens. These activated dendritic cells in turn activate naïve T cells into acquiring a T helper cell 2 (Th2) 
phenotype, which in turn promote inflammatory signals which induce food Ag-specific B cells to class switch and produce food antigen-specific IgE. In short, sensitization is mistaken identification of food antigen as pathogen. All patients with IgE-mediated food allergies are sensitized to food allergen. This section will discuss five key components of the immune system involved in the development of tolerance and sensitization or allergy to food: the epithelium, innate immune cells, $\mathrm{T}$ cells, B cells, and finally, the effector cells of the allergic response, mast cells, eosinophils, and basophils (Fig. 3).

\section{Epithelial Barrier}

The epithelial barrier serves a major role in defense against pathogens. In the context of IgE-mediated food allergies, the epithelial barrier prevents unnecessary entry of antigens. An intact epithelial barrier is important in the maintenance of tolerance, as it prevents the entry of danger signals and subsequently prevent the production of inflammatory cytokines, in conjunction with food antigens. Antigens cannot freely pass an intact epithelial barrier. Instead, in an intact epithelium, antigen is often transported through "assisted" mechanisms. These mechanisms include: paracellular diffusion, active transport via the enterocytes, microfold (M) cells, or goblet cells, and by specialized macrophages projecting through epithelial [3]. Food antigens recognized by specialized antigen presenting cells in the absence of pro-inflammatory or danger signals will further promote the maintenance of tolerance through the release of chemical mediators such as interleukin 10 (IL-10) and/ or transforming growth factor beta (TGF- $\beta$ ), which will promote the development of regulatory T cells [4-6].

When the integrity of the epithelial barrier is compromised, sensitization to food allergens can occur, leading to the development of food allergy. Epithelial damage or inflammation can allow antigens to pass freely through the gut barrier, along with other pathogens. Damaged epithelium also promotes the release of pro-inflammatory epithelial cytokines, such as interleukin 25 (IL-25), IL-33, and thymic stromal lymphopoeitin (TSLP) [7, 8]. The epithelial cytokines released can foster the activation of an allergic phenotype by signaling to antigen presenting cells and other innate immune cells at or below the epithelial barrier. When food antigen uptake occurs by activated antigen presenting cells in the presence of inflammatory cytokines, the benign antigen is now seen as a "threat."

\section{Antigen Presenting Cells and Innate Lymphoid Cells}

In the absence of sensitizing chemical mediators, CX3CR1+ macrophages can sample antigen and produce the cytokine IL10 , which will allow for the differentiation of naïve $\mathrm{T}$ cells to regulatory T cells. CD103+ dendritic cells can also capture antigen directly or from transfer by the macrophage [9]. CD103+ DCs will migrate to draining lymph nodes and present the antigenic peptide along with the class 2 major histocompatibility complex (MHC) to naïve T cells. Furthermore, in the presence of TGF- $\beta$ and retinoic acid secreted from the DCs, naïve $\mathrm{T}$ cells are promoted toward a tolerant phenotype and can differentiate to T regulatory cells [5].

Conversely, the breakdown of tolerance due to a compromised epithelial barrier, promotes the epithelial release of proinflammatory chemical mediators, such as IL-25, IL-33, and TSLP [7, 8]. These mediators act upon antigen presenting cells and innate lymphoid cells, to further promote sensitization by a Th2 phenotype. Activated dendritic cells promoting allergy, express surface OX40L, also known as tumor necrosis factor ligand superfamily member 4 (TNFSF4) and migrate to the draining lymph node where they encounter and present antigen to naïve T cells [10]. The MHC of the dendritic cell presents antigenic food peptides to naïve T cells and with the interaction between OX40L on DCs and OX40 on naïve T cells, differentiation occurs from naïve T cells into Th2 T cells, thus promoting the allergic state.

In addition to activated dendritic cells, type 2 innate lymphoid cells (ILC2) have also been shown to play a critical role in the induction of food allergy. ILC2s expand in an antigenindependent manner while in the presence of the cytokines TSLP, IL-25, and IL-33 and promote a Th2 cell-mediated immune response [11]. As a result, ILC2s produce large quantities of $\mathrm{T}_{\mathrm{H}} 2$ cytokines, such as IL-5, IL-13, IL-4, and IL-9 [12-14]. The secretion of the cytokine IL-4 and IL-13 from ILC2s can disrupt allergen-specific T regulatory cell induction and their suppressive functions, as well as enhance mucosal mast cell activation, thereby sustaining dysregulation and promoting the induction of food allergies [11].

\section{T Cells}

The appropriate milieu of cytokine and innate cell mediators promote the development of tolerance through naïve $T$ cells. Naïve $T$ cells reside in the draining lymph nodes and await for the upstream signals, and, in combination with the presented antigens, promote the development of $\mathrm{T}$ regulatory cells. Specifically, antigen presenting cells secreting TGF- $\beta$, retinoic acid, or IL-10, foster the development of antigenspecific $\mathrm{T}$ regulatory cells from the naïve $\mathrm{T}$ cells [4-6]. Specifically, retinoic acid from DCs promotes the expression of homing receptor $\alpha 4 \beta 7$ on $\mathrm{T}$ regulatory cells thereby allowing for the translocation to the intestinal lamina propria, where they exhibit suppressive activity via CTLA-4 binding to effector $[15,16]$. Furthermore, cytokines secreted from $\mathrm{T}$ regulatory cells, such as IL-10 and TGF- $\beta$, can also suppress effector cells [17].

Th2-differentiated cells can migrate out of the draining lymph nodes into the lamina propria and secrete proinflammatory cytokines, such as IL-5 and IL-13 to further promote the differentiation of downstream pro-inflammatory 


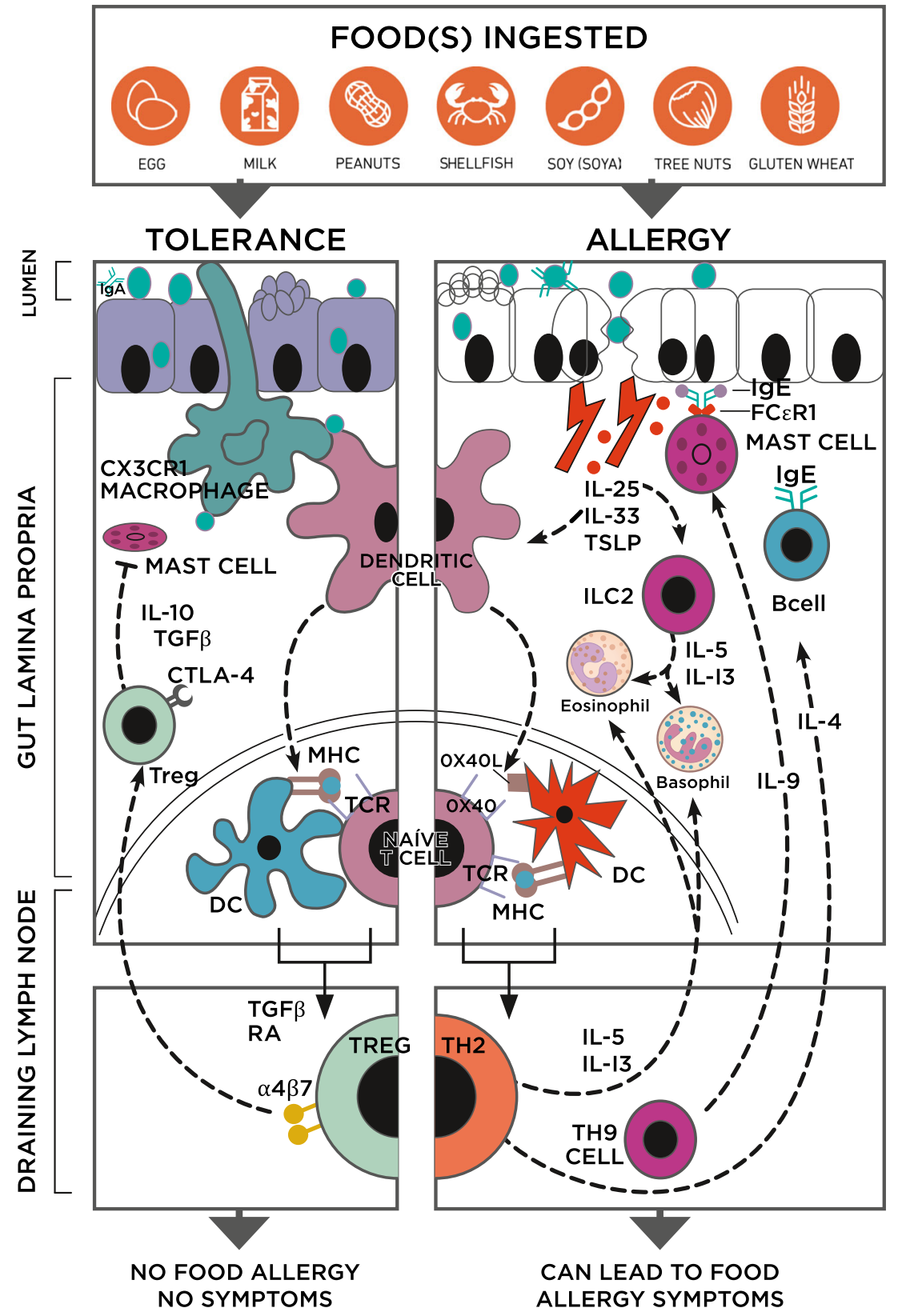

Fig. 3 Comparative overview of the tolerogenic versus allergic response to food antigen in the gut. Tolerance (left): food antigens are sampled from the intestinal lumen by CX3CR1 macrophages, which then transfer the antigen to dendritic cells in the gut lamina propria. Dendritic cells (DCs) can transfer processed antigen to the draining lymph nodes, and in the context of non-inflammatory mediators, such as transforming growth factor-beta (TFG- $\beta$ ) and retinoic acid, DCs present food peptide by way of the major histocompatibility complex (MHC) to the T cell receptors (TCR) on naïve T cells. This interaction promotes the differentiation of naïve $T$ cells into food antigen-specific $T$ regulatory cells (Tregs). Foodspecific Tregs then travel to the lamina propria via $\alpha 4 \beta 7$ where they encourage the maintenance of tolerance to food antigen via CTLA-4 expression and the release of cytokines TGF- $\beta$ and IL-10. CTLA-4 inhibits Th2 T cells while TGF- $\beta$ and IL-10 suppress the effector cells that promote allergy such as mast cells and also encourages the maintenance of $\operatorname{IgA}$ in the lumen. Allergy (right): in the presence of gut epithelial damage, pro-inflammatory cytokines, such as IL-33, IL-25, and thymic stromal lymphopoietin (TSLP) are secreted and promote the expansion of type 2 innate lymphoid cells (ILCs) and activation of dendritic cells. Activated DCs, in the presence of these proinflammatory cytokines, will take up and process antigen to peptide and upregulate the expression of the surface protein OX40L. The peptide: major histocompatibility complex (MHC) on DCs and TCR on the naïve T cells interact, as well as the OX40L on DCs and OX40 on naïve $T$ cells. This interaction promotes the differentiation of naïve $T$ cells to type 2 helper T cells (Th2). Th2 cells and ILCs can secrete proinflammatory cytokines such IL-5 and IL-13, thereby promoting eosinophil and basophil recruitment in the gut lamina propria leading to downstream target effects that promote allergic sensitization. Th2 cells also secrete IL-4, which allows for B cell class switching to promote foodspecific IgE production. Th9 cells also play a major role in the development of the allergic response by secretion of IL-9, which promotes the recruitment of mast cells 
effector cells such as eosinophils and basophils. IL-4, which is produced by Th2 cells, promotes B cell class switching to produce $\mathrm{IgE}$ in order to further establish sensitization and an allergic response to food. In addition to Th2 cell activation, naïve $T$ cells have also been shown to differentiate to $T$ helper 9 cells. Th9 cells contribute to the development of the allergic response by secreting IL-9, which further promotes the accumulation of tissue residing mast cells [18].

\section{Effector Cells (Mast Cells and Basophils)}

Tissue residing mast cells and circulating basophils are important in the allergic process. In the presence of IL-10 and TGF- $\beta$, B cells can produce IgA antibodies which are important in the maintenance of tolerance. Elevated food-specific IgA antibodies are associated with desensitization and the state of sustained unresponsiveness in patients who have oral immunotherapy to food. The exact mechanism of the facilitation of tolerance by IgA is not known but seems dependent upon the innate immune system $[19,20]$. Furthermore, tolerance occurs in the absence of food-specific IgE. In its absence, the effector mast cells and basophils cannot degranulate.

In the presence of IL-4, B cell class switching occurs and food-specific $\operatorname{IgE}$ is produced, thereby promoting a state of sensitization and allergy. Antigen food-specific IgE binds to the FceRI receptors on mast cells and basophils. Upon exposure to antigen, cross-linking of IgE and the IgE receptors occur on the surface of mast cells and basophils resulting in the release of preformed mediators into circulation. The mediators involved in anaphylaxis include: histamine, tryptase, platelet activating factor, prostaglandins, and leukotrienes [20].

Histamine is one of the most important preformed mediators of anaphylaxis. Once released from the activated mast cell or basophil, histamine's onset of action is rapid (within $5 \mathrm{~min}$ ); however, it is quickly metabolized (half-life $30 \mathrm{~min}$ ). In anaphylaxis, histamine acts upon $\mathrm{H} 1$ and $\mathrm{H} 2$ receptors and stimulation of these receptors leads to vasodilation, increased vascular permeability, increased heart rate, increased cardiac contraction, and increased glandular secretion.

Tryptase, another preformed mediator primarily stored in mast cells, has limited diffusion from an activated mast cell because it is secreted as an active proteoglycan complex [21]. Tryptase levels peak at 60-90 min after the onset of [22]. In anaphylaxis, tryptase can cause angioedema by the activation of the contact (kallikrein-kinin) system. Platelet activating factor is a potent mediator of anaphylaxis. It causes bronchoconstriction, increased vascular permeability, chemotaxis, and degranulation of eosinophils and neutrophils. Prostaglandins are lipid mediators that are released from activated mast cells during anaphylaxis. Basophils do not produce prostaglandin D2 (PGD2), a prostaglandin only produced in mast cells. PGD2 causes bronchoconstriction, peripheral vasodilation, and coronary and pulmonary artery vasoconstriction, acting to recruit basophils, eosinophils, dendritic cells, and Th2 cells and enhance the release of histamine from basophils. Leukotrienes are also lipid mediators with a slow onset of action. They cause smooth muscle contraction, mucus secretion and cause increase vascular permeability. They are also important in the recruitment of allergic inflammatory cells and modulating the production of inflammatory cytokines.

The five components of the immune system, the epithelium, innate immune cells, T cells, B cells, and effector cells (mast cells, eosinophils, and basophils), can either promote tolerance to food antigens or sensitization, leading to allergic manifestations. Genetic and environmental factors can influence the immune system. As more is discovered about these influences, the underlying pathophysiology of IgE-mediated food allergy may be altered to promote tolerance or a state of desensitization (absence of clinical symptoms on exposure to food).

\section{Clinical Manifestations}

IgE-mediated food-allergic reactions are type I hypersensitivity reactions which occur when patients develop IgE antibodies against the culprit food protein followed by an exposure to that protein $[1,23]$. Usually, there are preformed circulating $\operatorname{IgE}$ antibodies in the peripheral circulation. Therefore, when the culprit food protein penetrates through the intestine lining, $\operatorname{IgE}$ antibodies bind to the food protein. Two adjacent $\operatorname{IgE}$ molecules binding to the food protein cause degranulation of the mast cell and basophil followed by preformed mediator release within minutes of exposure [20]. Therefore, the typical symptoms of an IgE-mediated food-allergic reaction are usually rapid in onset and can cause death. The typical symptoms can involve almost every organ system, including the skin, respiratory tract, gastrointestinal, cardiovascular, and neurological systems [24, 25] (Table 1).

Cutaneous manifestations include erythematous rashes, pruritus, urticaria, and angioedema. Mild symptoms may present as occasional scratching or persistent pruritus with or without hives. Hives consist of circumscribed dermal edema surrounded by erythema which usually blanches with pressure and are characteristically pruritic. They usually occur immediately after ingestion of the culprit food and can last for hours without treatment. Angioedema usually presents as eyelid, face, and/or lip swelling and can cause significant amount of discomfort. Erythematous macular rash without hives can be one of the manifestations as well. Eczematous rashes can also be a symptom of IgE-mediated food allergy, although nonIgE-mediated immune mechanisms also play a role. Severity of the cutaneous symptoms in IgE-mediated food allergy can be determined by the percentage of the involved skin [26]. 
Table 1 Clinical manifestations of IgE-mediated food allergy by organ system

\begin{tabular}{|c|c|c|c|c|}
\hline Organ systems & Symptoms & Mild & Moderate & Severe \\
\hline \multirow[t]{3}{*}{ Skin } & Rash & Faint erythema & Erythema & $\begin{array}{l}\text { Generalized marked erythema (more } \\
\text { than } 50 \% \text { of the body surface area) }\end{array}$ \\
\hline & Urticaria/angioedema & $<3$ areas of hives; mild lip edema & $\begin{array}{l}\text { More than } 3 \text { areas of hives; } \\
\text { significant lip or face edema }\end{array}$ & $\begin{array}{l}\text { Generalized involvement of swelling } \\
\text { face/lips/eyelids }\end{array}$ \\
\hline & Pruritus & Occasional scratching & Scratching continuously & Continuous scratching; excoriations \\
\hline Upper airway & Sneezing/itching & Occasional sniffing & $\begin{array}{l}\text { Intermittent rubbing of nose or eyes; } \\
\text { frequent sniffing }\end{array}$ & $\begin{array}{l}\text { Continuous rubbing of nose or eyes; } \\
\text { periocular swelling; persistent } \\
\text { rhinorrhea }\end{array}$ \\
\hline \multirow[t]{2}{*}{ Lower airway } & Wheezing & Expiratory wheezing & Inspiratory and expiratory wheezing & $\begin{array}{l}\text { Use of accessory muscles; audible } \\
\text { wheezing; increased work of } \\
\text { breathing }\end{array}$ \\
\hline & Laryngeal manifestation & $\begin{array}{l}\text { Episodes of throat clearing or cough; } \\
\text { persistent throat tightness }\end{array}$ & Hoarseness, frequent cough & Stridor \\
\hline \multirow[t]{2}{*}{ Gastrointestinal tract } & Subjective symptoms & Nausea or mild abdominal pain & $\begin{array}{l}\text { Moderate abdominal pain with } \\
\text { normal activity }\end{array}$ & $\begin{array}{l}\text { Notably distressed due to GI } \\
\text { symptoms with decreased activity }\end{array}$ \\
\hline & Objective symptoms & 1 episode of emesis or diarrhea & $\begin{array}{l}\text { More than } 1 \text { but less than } 3 \text { episodes } \\
\text { emesis or diarrhea }\end{array}$ & $\begin{array}{l}\text { More than } 3 \text { episodes of emesis or } \\
\text { diarrhea }\end{array}$ \\
\hline Cardiovascular/Neurological & & $\begin{array}{l}\text { Subjective weakness, dizziness; } \\
\text { tachycardia }\end{array}$ & $\begin{array}{l}\text { Drop in blood pressure; significant } \\
\text { change in mental status (anxiety, } \\
\text { confusion) }\end{array}$ & $\begin{array}{l}\text { Severe cardiovascular collapse; } \\
\text { unconsciousness }\end{array}$ \\
\hline Other & & & Loss of bladder control & Pelvic pain \\
\hline
\end{tabular}

Cutaneous manifestations are the most common IgE-mediated food-allergic symptoms.

IgE-mediated food-allergic respiratory symptoms can involve the upper and lower airway tract. Mild symptoms present as mild occasional sniffing or rubbing of the nose. Moderate to severe symptoms can present as persistent rhinorrhea or nasal congestion, including a complete blockage of the nares. Other than the upper airway tract, ocular symptoms can occur in isolation or in combination with the upper airway symptoms. Conjunctival involvement can present as lacrimation, eye redness, and/or itching, and ocular severe symptoms can manifest as significant periorbital swelling $[1,24,25]$.

Lower upper respiratory tract symptoms include wheezing with mild symptoms of expiratory wheeze and increasing symptom severity including inspiratory wheeze, audible wheezing, use of accessory muscles. or an asthma exacerbation. Asthma exacerbation can also occur when inhalation of the food protein has occurred, mediated by a type I hypersensitivity reaction. Laryngeal manifestations in IgE-mediated food-allergic reactions include throat clearing, cough, throat tightness, or throat pain. Moderate laryngeal symptoms include hoarseness and increased frequency of dry cough. The most-severe symptom could be stridor followed by complete airway obstruction. Stridor as an abnormally high-pitched sound occurs in inspiratory phase due to tissue swelling caused by allergic mediators in laryngeal tissues, such as the supraglottis, glottis, subglottis, or trachea, and subsequently interrupting and narrowing the airway passage [24].

Gastrointestinal involvement includes subjective and objective symptoms. Subjective symptoms include itching of mouth or throat, nausea, or abdominal pain. Objective symptoms include vomiting and intermittent or persistent diarrhea. The onset of the gastrointestinal system symptoms is usually immediate, often within minutes and not more than 2 to $4 \mathrm{~h}$.
Symptoms such as failure to thrive, bloody diarrhea, constipation, weight loss, long-term malabsorption, emesis, or diarrhea after $4 \mathrm{~h}$ of food ingestion are typically not IgE-mediated food-allergic manifestations, but non-IgE mediated, usually occurring as a result of cellular innate and adaptive immune mechanisms [1].

Cardiovascular system and neurological involvement are the most severe manifestations of IgE-mediated food-allergic reactions in patients. Subjective symptoms include dizziness or weakness; objective signs may include tachycardia, hypotension, change in mental status, severe cardiovascular collapse, unconsciousness, and death. Cardiovascular symptoms and neurological involvement usually occur with other organ involvement, such as respiratory or cutaneous manifestations [1,24].

Anaphylaxis is a severe form of an IgE-mediated hypersensitivity allergic reaction that involves multiple organs. It is rapid in onset and is potentially fatal. A non-anaphylactic mild allergic reaction is defined by acute reactions caused by generalized release of mediators restricted to one system; for example, a patient could have that or other cutaneous findings, such as pruritus, erythematous rash, urticaria, local edema, or angioedema with no other system involvement. Anaphylaxis is by definition a severe allergic reaction with more than one system involved (Table 2). Anaphylaxis symptoms can involve the above cutaneous reactions along with respiratory, gastrointestinal, cardiovascular, or neurological system involvement. Even though it is rare, anaphylaxis can also present with only cardiovascular or neurological symptoms, such as dizziness, weakness, tachycardia, hypotension, cardiovascular collapse, or unconsciousness [24].

The World Health Organization classified anaphylaxis into five grades [27] (Table 3). Grade I is defined when only one organ system is involved - including cutaneous, respiratory, ocular, or others. Cutaneous signs and symptoms according to this 
Table 2 Definition of anaphylaxis

Anaphylaxis is highly likely when any 1 of the following 3 criteria is fulfilled:

Acute onset of an illness (minutes to several hours), with involvement of the skin, mucosal tissue, or both (e.g., generalized urticaria, itching or flushing, swollen lips/tongue/uvula), and at least 1 of the following: (1) respiratory compromise (e.g., dyspnea, wheeze/bronchospasm, stridor, hypoxemia) or (2) reduced blood pressure or associated symptoms of end-organ dysfunction (e.g., hypotonia (collapse), syncope, incontinence)

2 or more of the following that occur suddenly after exposure to a likely allergen for that patient (minutes to several hours): (1) involvement of the skin/mucosal tissue (e.g., generalized urticaria, itch/flush, swollen lips/tongue/uvula), (2) respiratory compromise (e.g., dyspnea, wheeze/bronchospasm, stridor, hypoxemia), (3) reduced blood pressure or associated symptoms (e.g., hypotonia (collapse), syncope, incontinence), or (4) persistent gastrointestinal symptoms (e.g., crampy abdominal pain, vomiting)

Reduced blood pressure after exposure to a known allergen for that patient (minutes to several hours): (1) for infants and children, low systolic blood pressure (age-specific) or greater than $30 \%$ decrease in systolic blood pressure and (2) for teenagers and adults, systolic blood pressure of less than $90 \mathrm{mmHg}$ or greater than $30 \%$ decrease from that person's baseline

classification include generalized pruritus, urticaria, flushing, or sensation of heat or warmth or angioedema not involved in laryngeal, tongue, or uvular tissues. Localized hives or angioedema alone would not be considered anaphylaxis. Upper respiratory tract symptoms include sneezing, rhinorrhea, nasal pruritus and/ or nasal congestion, throat clearing, itchy throat, and coughing. Conjunctival symptoms include conjunctival erythema, pruritus, or tearing. Other symptoms may include nausea, metallic taste, or headache. Grade II anaphylaxis is defined when there are two organ systems involved or lower respiratory tract involvement, gastrointestinal involvement, or uterine cramping. Lower respiratory tract symptoms in grade II anaphylaxis include wheezing, shortness of breath, and a drop of the forced expiratory volume in $1 \mathrm{~s}$ (FEV1) by $40 \%$ which is responsive to bronchodilator medication. Gastrointestinal symptoms in grade II anaphylaxis includes abdominal cramping, vomiting, or diarrhea. Grade III anaphylaxis occurs when symptoms of laryngeal, uvular, or tongue tissue edema occur with or without stridor or when the FEV1 drops by $40 \%$ with no bronchodilator response. Grade IV symptoms include respiratory failure or hypotension. Grade V anaphylaxis is death. Biphasic reactions occur in $\sim 10 \%$ of anaphylactic episodes.

Many studies had shown that clinical manifestations differ among different age groups. Infants with anaphylaxis more often present with vomiting and hives; preschool age children with anaphylaxis often present with wheezing and stridor. Subjective symptoms including difficulty breathing or difficulty swallowing are the more common presenting symptoms for anaphylaxis in teenager age group. Three percent of children have hypotension as their presenting symptom of anaphylaxis [28].

Eight foods cause $90 \%$ of IgE-mediated food-allergic reactions: cow's milk, egg, soy, wheat, shellfish, fish, peanuts, and tree nuts [1]. The natural history of cow's milk, egg, soy, and wheat IgE-mediated allergy is resolution from childhood to adulthood. Shellfish, fish, peanut, and tree nut allergies rarely resolve, with only $20 \%$ of peanut-allergic children and $10 \%$ of tree nut-allergic children having resolution. Resolution of food-allergic disease is accompanied by a decrease in serum food-specific IgE level so these levels can be serially followed to help predict disease resolution [2]. Egg- and cow's milkallergic patients begin to tolerate extensively baked goods with denaturation of the proteins before tolerating unbaked milk and egg [29].

\section{Diagnostic Approaches}

The initial food allergy workup begins with obtaining a detailed clinical history and physical exam. The information provided in the history can support the necessary testing, in order to identify the cause of the reaction. The diagnosis relies on the history and test results; however, testing is not $100 \%$ diagnostic and results should be interpreted carefully. The gold standard to diagnosing a food allergy is to perform an

Table 3 World allergy organization grading and definition of types of anaphylaxis

\begin{tabular}{|c|c|}
\hline Grade & Definition \\
\hline \multicolumn{2}{|l|}{ Anaphylaxis } \\
\hline Grade I & Only 1 organ system is involved - including cutaneous, respiratory, ocular \\
\hline Grade II & 2 organ systems involved or lower respiratory tract, gastrointestinal involvement, or uterine cramping \\
\hline Grade III & $\begin{array}{l}\text { Symptoms of laryngeal, uvular, or tongue tissue edema occur with or without stridor or when the FEV1 } \\
\text { drops by } 40 \% \text { with no bronchodilator response. }\end{array}$ \\
\hline Grade IV & Respiratory failure or hypotension \\
\hline Grade V & Death \\
\hline Biphasic anaphylaxis & $\begin{array}{l}\text { New or worsening anaphylactic symptoms after resolution of the primary/first reaction. Usually occurs } \\
\text { within } 6 \mathrm{~h} \text { after the resolution of the primary reaction. }\end{array}$ \\
\hline Refractory anaphylaxis & Anaphylactic reaction that does not respond to initial treatment \\
\hline
\end{tabular}


oral food challenge. Herein, the current diagnostic approaches to identifying an IgE-mediated food allergy are discussed.

\section{Clinical History and Physical Exam}

One of the most essential aspects in the workup for food allergies is obtaining an accurate and detailed history. When obtaining the history, the following questions should be addressed: (1) the exact food causing the symptoms and its preparation (cooked or uncooked); (2) the amount of food triggering the reaction; (3) the symptoms experienced at the time of reaction; (4) the time from ingestion to symptom development; (5) factors that may have contributed to the reaction (i.e., viral illness, medications, exercise); (6) treatments used to stop the reaction; (7) the presence of a biphasic reaction following the initial symptoms; (7) reproducibility following a subsequent exposure; and (8) length of time since the last reaction. In addition to the details of the reaction, the clinician should also focus on patient's history of other forms of atopy, such as atopic dermatitis, asthma, or allergic rhinitis. There is a strong association between atopic dermatitis and the development of food allergies, especially when the severe atopic dermatitis is acquired in the first 3 months of life [30,31]. Hill et al. described a birth cohort of 480 children followed for development of atopic dermatitis. The relative risk of an infant with atopic dermatitis having IgE-mediated food allergy was 5.9 for the most severely affected group [30]. In population-based studies, the likelihood of food sensitization was up to six times higher in patients with $\mathrm{AD}$ versus healthy control subjects at 3 months of age [31]. Thus, with eczema being a risk factor for the development of food allergies, clinicians should inquire about the age of onset of the eczema and its severity.

Further information in the clinical history should also include the patient's family history of atopy, including food allergies. The information obtained from the clinical history will not only provide information to identify the potential trigger causing the reaction but will also determine the necessary tests to facilitate the diagnosis of a food allergy. Overall, the history provides the necessary information to determine the necessity for any testing and whether a food challenge would be appropriate.

\section{Testing-Skin Testing and Serum-Specific IgE Testing}

In addition to the detailed medical history and physical examination, when suspecting an IgE-mediated food allergy, the practitioner can utilize clinically approved tests, to aid in the diagnostic workup. Commonly utilized tests such as the immediate hypersensitivity skin test and food-specific IgE antibody tests are utilized in the evaluation of an IgE-mediated food allergy. It is important for general practitioners and allergists to be aware of the dangers of ordering large panels of tests which can lead to false-positive results and potentially unnecessary dietary eliminations. In addition, a 4-6-week waiting period after an anaphylaxis episode should be given before skin testing is performed.

Immediate hypersensitivity skin testing (IHST) is a rapid method of screening for the presence of food-specific IgE antibodies bound to cutaneous mast cells. The test is performed by using a device coated with commercial extract or fresh food and scratching the surface of the skin. This introduces the food protein through the skin, which can then bind to specific IgE on cutaneous mast cells and trigger degranulation of preformed mediators like histamine. The activation of the local mast cells produces a wheal and flare visualized at the site where the allergen was introduced through the skin. The wheal is measured 15 min after the prick and the diameter of the wheal provides information on the likelihood of clinical reactivity. A mean wheal diameter $\geq 3 \mathrm{~mm}$ larger than the negative control is considered a positive skin test and could suggest the likelihood of clinical reactivity [32]. However, a positive skin-prick test (SPT) only reflects the presence of specific IgE antibodies bound to mast cells and is not diagnostic of clinical reactivity. The presence of specific IgE antibodies without clinical reactivity is called sensitization. Therefore, caution should be made when interpreting results and only suspected food allergens should be tested, since food skin testing has a low specificity $[33,34]$.

A positive skin test cannot differentiate between sensitization and a true IgE-mediated allergy; therefore, it is important that the clinician combine a detailed clinical history and the results of a test to determine the need for additional diagnostic testing to support an IgE-mediated food allergy. Although wheal size does not correlate with disease severity, positive predictive values for clinical reactivity have been reported based on the size of the wheal diameter. For example, a mean wheal diameter size $\geq 8$ $\mathrm{mm}$ for cow's milk, $\geq 7 \mathrm{~mm}$ for hen egg, and $\geq 8 \mathrm{~mm}$ for peanut was $95 \%$ predictive of reaction if challenged [35]. Skin-prick tests have a relatively high NPV and can be particularly useful in ruling out IgE-mediated food allergy to a specific food. However, clinical reactivity occasionally occurs with a negative skin-prick test [2]. Intracutaneous testing, also called intradermal testing, for the diagnosis of food allergy is not recommended given the risk of serious adverse reactions [2].

Food-specific and food-component $\mathrm{IgE}$ antibody testing are additional diagnostic measurements that can be used to measure food-specific IgE antibodies. The measurement of $\operatorname{IgE}$ is performed by the technique of fluorescence enzyme labelling. The patient's serum is incubated with a surface-fixed allergen, and food-specific IgE from the patient binds to the allergen. The food-specific IgE is then identified with a fluorescently labeled anti-IgE antibody. The measurement provides evidence of unbound circulating allergen-specific IgE levels produced. Food-specific IgE levels correlating with a $95 \%$ positive predictive value for several foods have been previously determined and can potentially correlate with a reaction to a given 
food. One hundred children ( $62 \%$ male; median age, 3.8 years; range, $0.4-14.3$ years) were evaluated for food allergy and diagnosed by history or oral food challenge. On the basis of the previously established $95 \%$ predictive decision points for egg, milk, peanut, and fish allergy, greater than $95 \%$ of food allergies diagnosed in this prospective study were correctly identified by quantifying serum food-specific IgE concentrations $[36,37]$. For example, the positive predictive value for a peanut IgE level greater than $14 \mathrm{kU} \mathrm{L}^{-1}$ and the peanut component Ara h2 greater than $5 \mathrm{kU} \mathrm{L}^{-1}$ has been shown to be 100 and $96 \%$, respectively $[36,38]$. A diagnostic prediction model for peanut allergy in children using six predictors: sex, age, history, skin-prick test, peanut-specific immunoglobulin E (sIgE), and total IgE minus peanut sIgE. When building the model with sIgE to peanut components, Ara $\mathrm{h} 2$ was the only predictor, with a discriminative ability of $90 \%$. The outcome of the food challenge could be predicted with $100 \%$ accuracy in $59 \%$ (updated model) and 50\% (Ara h2) of the patients. Therefore, values above $5 \mathrm{kU} \mathrm{L}^{-1}$ are highly suggestive of an IgE-mediated peanut allergy.

Ultimately, specific IgE levels should be interpreted with caution when the history is not supportive of an IgE-mediated allergy, especially given the high false-positive rates. In cases where the history is strongly supportive of tolerance to a food, for example, if the patient has eaten a large amount of the food recently without symptoms, it is better to avoid testing specific IgE levels. Like food allergen skin testing, the sensitivity of serum IgE testing is greater than $90 \%$; however, the specificity of both tests can be less than $50 \%$ when assessing foods, due to possible cross-reactivity between related proteins [2] (Table 4). Therefore, these tests cannot rule out a food allergy and cannot differentiate between sensitization versus a true IgE-mediated allergy. The information obtained from the clinical history is crucial and should help guide the interpretation of the results obtained from these tests. Patients should be considered for a supervised oral food challenge when testing is negative for skin and blood and there has been diet avoidance of the food. If there are discrepant test results and clarification of a diagnosis is needed, a challenge is helpful.

\section{Oral Food Challenge}

An oral food challenge can provide a definitive diagnosis for an IgE-mediated food allergy, and the double-blind placebocontrolled food challenge (DBPCFC) is the gold standard to diagnosing food allergies in clinical trials or standardized studies [39]. The history and test results will allow the clinician to determine whether or not to pursue the challenge. Performing an oral challenge requires an experienced clinician who can quickly recognize and treat symptoms of anaphylaxis. In addition to a DBPCFC, food challenges can also be open or single blind. The patient undergoing an oral challenge begins with ingesting very small amounts of the food, masked in a vehicle, and the doses are increased every 15-30 min until all steps have been completed or until symptoms present. In preparation for an oral challenge, patients discontinue medications, such as antihistamines or corticosteroids, which can interfere with the results of the challenge. Furthermore, coexisting conditions such as asthma, uncontrolled urticarial or eczema, or a concurrent respiratory tract infection should be evaluated before performing an oral food challenge. Thirtytwo cases of fatal food anaphylaxis cases have been documented and uncontrolled asthma identified as a comorbid condition in $97 \%$ of these cases. Patients with uncontrolled asthma should be carefully evaluated and controlled before undergoing an oral food challenge as they could be at risk of a severe fatal reaction [2].

\section{Other Tests}

The use of alternative tests, such as the allergen-specific IgG or IgG4 testing, lymphocyte stimulation, cytotoxicity assays, mediator release test, provocation neutralization, applied kinesiology, or hair analysis testing have not been currently recommended as validated tools in the diagnostic workup for IgE-mediated food allergies [2]. Although many patients may have these tests performed, the interpretation of these tests has not been rigorously assessed as reliable. Patients should be discouraged from having these tests because they are very costly and could result in unnecessary dietary avoidance.

\section{Treatment of IgE-Mediated Food Allergies}

Anaphylaxis to IgE-mediated food allergies leads to symptoms which have been previously described including but not limited to rash, vomiting, diarrhea, abdominal pain, wheezing, chest pain, clearing throat, tongue swelling, lip swelling, and hypotension. These IgE-mediated reactions need immediate management to stabilize the patient as well as long-term management and monitoring.

\section{Acute Management}

\section{a. Recognize anaphylaxis}

The first step in management of a suspected IgE-mediated allergic reaction to food is assessment to identify anaphylaxis, which is a potentially life-threatening condition. A large, international study published in April 2016 collected anaphylaxis data from July 2007 to March 2015. Patients with anaphylaxis were referred to 1 of 90 tertiary allergy centers in ten European countries. This allowed assessment of anaphylaxis in 1970 patients. The study showed symptoms included skin in $92 \%$ of children which were further characterized as angioedema (53\%), urticarial (62\%), pruritus (37\%), and erythema/ 
Table 4 Diagnostic cut-offs for immediate hypersensitivity skin-prick testing and serum food-specific IgE testing (positive predictive value (PPV), negative predictive value (NPV))

\begin{tabular}{|c|c|c|c|c|c|}
\hline \multirow{7}{*}{$\begin{array}{l}\text { Testing modality } \\
\text { Skin-prick testing }\end{array}$} & Foods & Sensitivity (\%) & Specificity (\%) & PPV 95\% & NPV $(50 \%)$ \\
\hline & & & & & \\
\hline & Peanut & 95 & 61 & $\geq 8 \mathrm{~mm}$ & $<3 \mathrm{~mm}$ \\
\hline & Hen egg & 92 & 58 & $\geq 7 \mathrm{~mm}$ & $<3 \mathrm{~mm}$ \\
\hline & Cow milk & 88 & 68 & $\geq 8 \mathrm{~mm}$ & - \\
\hline & Wheat & 73 & 73 & - & - \\
\hline & Soy & 55 & 55 & - & - \\
\hline \multirow{6}{*}{$\begin{array}{l}\text { Testing modality } \\
\text { IgE testing }\end{array}$} & Foods & Sensitivity (\%) & Specificity (\%) & PPV $\geq 95 \%(\leq 2$ years $)$ & \\
\hline & $\begin{array}{l}\text { Peanut } \\
\text { Ara h2 }\end{array}$ & 96 & 59 & $\begin{array}{l}14 \mathrm{kU} \mathrm{L}^{-1} \\
5 \mathrm{kU} \mathrm{L}^{-1}\end{array}$ & \\
\hline & Hen egg & 93 & 49 & $7\left(2 \mathrm{kU} \mathrm{L}^{-1}\right)$ & \\
\hline & Cow milk & 87 & 48 & $15\left(5 \mathrm{kU} \mathrm{L}^{-1}\right)$ & \\
\hline & Wheat & 83 & 43 & $26 \mathrm{kU} \mathrm{L}^{-1}$ (PPV 74\%) & \\
\hline & Soy & 83 & 38 & $30 \mathrm{kU} \mathrm{L}^{-1}$ (PPV 73\%) & \\
\hline
\end{tabular}

flush (29\%). The anaphylaxis symptoms also included gastrointestinal symptoms (45\%), respiratory in $80 \%$, cardiac in $41 \%$, and neurologic in $26 \%$ [40]. Being able to diagnose a patient with anaphylaxis is essential to the treatment. A patient may react the first time they consume a food or after previously tolerating a food. After initial exposure, subsequent exposures can result in more severe reactions.

\section{b. Epinephrine}

After the diagnosis of anaphylaxis, the first-line treatment is intramuscular epinephrine. Epinephrine can help vasoconstrict the blood vessels to maintain blood pressure, bronchodilate the airways to improve respirations, and decrease edema that may be causing airway collapse. The dosing for epinephrine is 0.01 up to $0.3 \mathrm{mg} \mathrm{kg}^{-1}$. This should be placed into the lateral thigh intramuscularly, as subcutaneous epinephrine injection does not result in quick systemic absorption. The dose of epinephrine autoinjectors are typically 0.15 and $0.30 \mathrm{mg}$, although a $0.10-\mathrm{mg}$ autoinjector has recently been approved by the US Food and Drug Administration. For patients under $25 \mathrm{~kg}$, the $0.15-\mathrm{mg}$ dose is recommended, and for those greater than $25 \mathrm{~kg}$, the $0.3-\mathrm{mg}$ dose is recommended [41]. All patients who have experienced one of the symptoms of anaphylaxis and have a diagnostic test positive for food-specific IgE should be given epinephrine in the event of an accidental exposure to the culprit food, especially because of the relationship between fatal anaphylaxis and delayed epinephrine administration.

Patients in the midst of anaphylaxis require constant monitoring. Furthermore, they may require fluid resuscitation with normal saline, oxygen, vital sign monitoring, and cardiopulmonary resuscitation [41]. In a recently published study, when a tertiary pediatric emergency department compared 2003/ 2004 with 2012 with a similar volume of total emergency room visits, 92 cases were coded and verified for anaphylaxis in 2003/2004 versus 159 cases in 2012. More of these cases were treated with epinephrine in $2012(28 \%)$ as well as given outpatient follow-up with allergy specialist (99.4\%) and an outpatient prescription for an epinephrine auto-injector (81\%) compared with 2003/2004 (12, 88, and 53\%, respectively) [42]. A key component of the management of foodallergic patient who present to the emergency department or physician's office includes discharge management plans. This study shows patients received better care as anaphylaxis was better identified, proper treatment was given, followed by instructions for follow-up care.

\section{c. Anti-histamines and glucocorticoids}

Following the use of intramuscular epinephrine, $\mathrm{H}_{1}$-antihistamines are the next treatment which should be used for anaphylactic symptoms. These should never be used alone for the treatment of anaphylaxis. They can help relieve symptoms as a single agent or in addition with $\mathrm{H}_{2}$-antihistamines. As allergic reactions can cause histamine release, giving medications that block the $\mathrm{H}_{1}$ and $\mathrm{H}_{2}$ receptors can improve the vasculature integrity and maintenance of the blood pressure and heart rate [43]. Glucocorticoids are often used in emergency room visits for anaphylaxis. In a prospective study published in 2017, anaphylaxis cases were evaluated from 2013 to 2014. Upon review, in 180 anaphylactic patients identified, 
$83 \%$ received glucocorticoids while only $25 \%$ received adrenaline [44]. There is an overall lack of evidence for clear benefit of glucocorticoids, but it is frequently used. It is essential to remember that similar to anti-histamines, glucocorticoids are not first-line treatment for anaphylaxis and should not be used in place of epinephrine. Although education has improved, further progress is needed.

\section{Long-term Management}

\section{a. Diagnosis of reaction (skin-prick testing)}

A patient must wait 4-6 weeks after an anaphylaxis episode to have skin testing performed. As discussed in the "Diagnostic Approaches" section, testing earlier than this increases the chance of a false negative. The diagnosis of IgE-mediated food allergy is discussed extensively in an earlier section and includes a combination of clinical history assessment of risk of food allergy and a test to document presence of food-specific $\operatorname{IgE}$ (skin-prick testing or specific IgE testing) [2, 34, 35].

\section{b. Avoidance of the food}

The first long-term management strategy of IgE-mediated food allergies is strict food allergen avoidance. The reason for subsequent reactions following initial diagnosis of IgEmediate food allergy is often the failure to avoid the known allergen. There are a number of concepts to discuss that ultimately affect a patient's ability to avoid a food allergen.

\section{i. Reading labels}

Every patient diagnosed with IgE-mediated food allergy should be counseled, preferably by a registered dietitian, about the strategies and vigilance required to avoid specific food allergens. This endeavor can be overwhelming for families and quite costly. A cross-sectional survey was conducted from 28 November 2011 to 26 January 2012 in 1643 US caregivers of a child with a current food allergy showed that the overall estimated economic cost of food allergy was $\$ 24.8$ (95\% CI, $\$ 20.6-29.4$ ) billion annually ( $\$ 4184$ year $^{-1}$ child $^{-1}$ ). Costs borne by the family totaled $\$ 20.5$ billion annually, with outof-pocket costs of \$5.5 (95\% CI, \$4.7-6.4) billion annually, with $31 \%$ stemming from the cost of special foods [45]. Due to the natural history of egg and milk IgE-mediated food allergies and the fact that not all patients have to avoid unbaked (nondenatured) and baked (denatured) egg and milk, the requirement to avoid food allergens can be difficult. Additionally, names for food allergens on labels can be counter intuitive (i.e., casein for milk or ovomucoid for egg).

Patients need help to navigate reading labels, and this may improve their nutritional status. Dietary counseling is an important aspect of the help parents need [46]. Ninety-one food- allergic children (mean age 18.9 months) were compared with controls and, at baseline, energy and protein intakes were lower in children with food allergy ( $91 \mathrm{kcal} \mathrm{kg}^{-1} \mathrm{day}^{-1}$ ) than in controls $\left(96 \mathrm{kcal} \mathrm{kg}^{-1} \mathrm{day}^{-1}\right)(p<0.001)$. A weight-to-length ratio $<2$ standard deviations was more frequent in children with food allergy compared with controls (21 versus 3\%; $p<0.001$ ). At 6 months following dietary counseling, the total energy intake of children with food allergy normalized. Dietary counseling also resulted in a significant improvement in markers of nutritional status.

On 1 January 2006 through the Food Allergen Labeling and Consumer Protection Act (FALCPA) of 2004, it became law for food manufacturing companies to list the eight major allergens including milk, egg, peanut, tree nuts, fish, crustacean shellfish, wheat and soy, on food labels. This law requires even trace amounts of the protein to be included. Apart from the FALCPA, companies are not regulated regarding advisory statements including "may contain..." or "processed in a factory..." This is a misconception about this law. A 2007 study discussed these advisory statements specifically related to peanut allergy [47], showing consumers were more likely to buy products that stated as "made in a facility that processes peanut" over products labels as "may contain peanut." The study found peanut protein in $10 \%$ of the 200 food products with an advisory statement and clinically significant levels of peanut with $>1 \mathrm{mg}$ of peanut or $>0.25 \mathrm{mg}$ of peanut protein in 13 products [47]. Because these products can cause reactions if eaten by patients with IgE-mediated food allergy, all food with precautionary labels or containing food allergen should be avoided.

A more recent study in 2017 that addressed the food allergy labeling and purchasing habits in the USA and Canada, with 6684 participants, $84.3 \%$ caregivers to a child with food allergies. The survey showed $12.3 \%$ would purchase food labeled as "may contain allergen," $40.3 \%$ would purchase labeled as "manufactured in a facility that also processes allergen", and $16.7 \%$ would purchase labeled as "manufactured on shared equipment with products containing allergen". Twenty-nine percent of those surveyed did not know there was a law required to report labels. Twenty-eight percent thought precautionary advisory labels were required by law, and almost $17 \%$ did not know if they were required [48]. This study further verifies that caregivers need to have better education on reading labels for foods as well as understanding of the laws that enforce food allergen labeling. Since these products with precautionary labels can have the allergen in them, not understanding the labels may lead to the risk of accidental exposure.

\section{ii. Eating out}

In a recently published cross-sectional, qualitative study, food allergies cause a significant problem for families when trying to eat out. It leads to anxieties, limitations, and 
sacrifices. Identifying these consequences of food allergies will allow providers and support networks to help the families cope with their concerns [49]. Data was collected from food service workers at 278 randomly selected restaurants to identify their understanding of food allergens and treatment. Overall the managers, food workers, and servers were knowledgeable about food allergens and had positive attitudes about accommodating those with food allergies; however, it was noted that $10 \%$ of workers thought a person with a food allergy could safely consume a small amount of the allergen. The study also showed that allergy training improved attitudes towards the patients with food allergies but not the knowledge [50]. For patient safety, discussing eating out as well as tactics on how to do it successfully are essential.

\section{iii. School attendance}

Children spend a great deal of time at school thus as the incidence of IgE-mediated food allergy increases, the schools need to act. A retrospective study performed in Maryland compared peanut-free schools, schools with peanut-free tables, and schools with no food policy. The research showed that the schools with a peanut-free table compared with the schools without a peanut-free table had lower rates of epinephrine administration. The incidence rate was 0.2 per 10,000 students for the peanut-free table school and then 0.6 per 10,000 students for the school without a policy in place. There was not a significant difference noted in peanut free schools versus schools with a peanut-free table. This study enforces the importance of having a policy in place that allows increased avoidance for the students with food allergy [51].

\section{iv. Transition of pediatric care into adulthood}

As in all pediatric diseases, there is a concern for compliance in the transition of care into adolescent and adulthood. A recent study conducted from February 2015 through May 2016 involved evaluating 141 undergraduate college students who have a physician-diagnosed food allergy. It found that there is an inconsistent adherence to food avoidance and there is a need for a strategy to encourage avoidance to prevent events [52]. A 6-year comparison study was completed by the University of Michigan looking at the impact of a food allergy awareness implementation across the campus. The rates of always carrying epinephrine, strict avoidance, and preparer awareness were below 50\% even after food allergy awareness implementation [53]. Teaching patients at an early age and continuing the education throughout adolescent and emphasizing it as they transition to young adulthood is important to try and improve the risk of exposure and the level of preparedness.

\section{c. Dietician consultation}

Having an IgE-mediated food allergy can be difficult to work into day-to-day life. Furthermore, having a food allergy can indicate that an important nutrient of the diet must be removed thus dietary consultation is important as well as close monitoring of weight in patients with IgE-mediated food allergy. A study done in 2002 further discusses the importance of assessing height, weight, and body mass index in patients with food allergies. Furthermore, it compared allergy patients with non-allergy-matched patients. It showed that children with two or more food allergies were shorter, based on height-for-age percentiles, than those with one food allergy. The study showed that the number of children who did not meet $67 \%$ of the DRI for calcium and vitamin D was statistically higher for those without nutrition counseling compared with those who had counseling $[54,55]$. The study did not specify the extent of counseling but overall implies the importance of any nutrition counseling. A systematic review in 2013 comparing four studies overall concluded that children with multiple food allergies have a higher risk of growth impairment and inadequate nutrient intake thus monitoring nutrition is essential [56].

\section{Prevention}

There has been an ongoing debate of whether to introduce a common allergen to a baby as early as possible or delay introduction. In January 2017, the American Academy of Pediatric changed their stance on when to introduce allergen following the publication of a landmark study known as the Learning Early About Peanut (LEAP) trial. The LEAP study included 640 infants ages 4-11 months of age with severe eczema and/ or egg allergy as well as a negative skin-prick test or one with $1-4 \mathrm{~mm}$ in size. They were randomized to two arms with one group avoiding peanuts until 60 months of age and another group receiving peanuts. Upon completion, those with negative skin-prick testing who avoided peanuts had a $13.7 \%$ prevalence versus those who consumed it had a $1.9 \%$ prevalence of peanut allergy. In addition, those with slightly positive skinprick testing had a peanut allergy prevalence of $35.3 \%$ in those who avoided and $10.6 \%$ in those who consumed. This study allowed the medical field to see the importance of early introduction of allergens [57, 58].

A study recently published in February 2018 further evaluated this early introduction of peanuts and even evaluated introduction through breast milk. The study noted that $58.2 \%$ of mothers ate peanuts while breast-feeding and $22.5 \%$ gave peanuts prior to 12 months of age. At 7 years of age, $9.4 \%$ of the children had peanut allergy. Interestingly enough, the lowest incidence at $1.7 \%$ was found in children whose mothers ate peanuts while breast-feeding and were introduced to peanuts before 12 months of age. If a mother did not do one of these 
actions, there was an increase in incidence of peanut sensitization [59]. This study further supports the American Academy of Pediatrics newly revised statement [60].

\section{Future Management}

\section{a. Oral immunotherapy}

Oral immunotherapy (OIT) is an emerging treatment for food allergy. It encompasses putting the allergen in a vehicle including milk and powder form and then giving it to foodallergic patients in an increasing manner. Giving patient's increasing doses of the food allows them to build a tolerance to the food and would ideally allow them to ingest the food without anaphylaxis symptoms. There are a variety of clinical trials currently underway to assess the different methods of immunotherapy. For OIT, dosing is increased slowly in 2-4-week intervals until a top maintenance dose is achieved. OIT has been used in milk, egg, wheat, peanut, tree nut, and shellfish allergies. An assessment of the efficacy of OIT with peanut allergy desensitization was assessed in a phase 2 randomized controlled trial published in Lancet 2014. Desensitization was noted in $62 \%$ ( 24 of 39 participants) in the peanut OIT group, and none of the control group ( 0 of 46) tolerated $800 \mathrm{mg}$ protein daily. Following that, 54\% tolerated a $1400-\mathrm{mg}$ challenge and $91 \%$ tolerated daily ingestion. Furthermore, the quality-oflife scores improved. This study shows that a patient's quality of life can improve after oral immunotherapy treatment [61].

\section{b. Epicutaneous immunotherapy}

Epicutaneous immunotherapy (EPIT) is a second type of immunotherapy currently under evaluation for food allergy treatment. It involves placing a patch with food allergen on the skin to promote systemic tolerance. The food allergen is absorbed through the skin. Randomized double-blind placebo-controlled studies have shown the efficacy for peanut allergy for this treatment to induce systemic tolerance to peanut, after 12 months of therapy $[62,63]$.

\section{c. Sublingual immunotherapy}

Sublingual immunotherapy (SLIT) is a third of immunotherapy currently being explored for food allergy treatment. Food proteins are placed under the tongue in increasing doses. A randomized double-blind placebo-controlled pilot study of sublingual versus OIT in peanut allergy assessed 21 subjects. There was a 10-fold increase in food challenge threshold after 12 months in all the patients completing the treatments. The threshold was significantly greater in active OIT group. Although adverse reactions were more common with OIT over SLIT, the skin testing as well as blood testing for IgE had significant changes [64].

\section{Food Allergy Misconceptions Debunked}

Despite popular belief, food-allergic reactions do not always result in risk of fatal anaphylaxis. Depending on the disease process, fatal allergic reactions secondary to foods are due to responses. Symptoms associated with IgE-mediated food allergies are typically observed within $2-3 \mathrm{~h}$ of ingestion. On the other hand, non-IgE-mediated reactions are more often delayed, as opposed to IgE-mediated reactions. Patients frequently present with gastrointestinal symptoms, such as profuse vomiting or diarrhea-associated food protein-induced enterocolitis syndrome, bloody stools with milk protein proctocolitis or reflux, abdominal pain, poor weight gain, or vomiting with eosinophilic esophagitis. Cutaneous findings, such as atopic dermatitis, can also be a manifestation of a non-IgE-mediated reaction to food. The distinction between the true potential for fatal anaphylaxis versus no potential for death with ingestion is an important one for families to understand. If symptoms are consistent with non-IgE-mediated food allergies, the family should be counseled about the lack of risk of death from anaphylaxis. Strict avoidance is not always necessary in this case. Avoidance of ingestion of large quantities of the food may be preferred in non-IgE-mediated food allergy.

Many patients and some physicians believe a positive test is always consistent with true food allergy. Evidence of food sensitization, the presence of a positive SPT wheal or food-specific $\operatorname{IgE}$ (fsIgE), does not necessarily correlate with clinical reactivity $[65,66]$. Furthermore, a positive SPT or food sIgE, cannot predict the severity of a clinical reaction $[67,68]$. Therefore, test results alone should not be considered diagnostic when determining whether a patient has a food allergy. It is important to obtain an accurate clinical history and utilize the information from SPT and sIgE testing, in order to determine the probability for a successful oral food challenge. The magnitude of the SPT and/or sIgE for the food, can help predict whether an individual may have a clinical reaction and cut-off values have been determined for milk, egg, peanut, and fish [35, 69-71].

Another misconception is that fish allergy is applicable to all species if a patient is diagnosed with allergy to one species. Patients allergic to certain fish may not experience clinical reactions to all species of fish. Parvalbumin, which is the most common allergenic protein in fish, has a different chemical structure depending on the species of fish. There are different specific IgE epitope recognition patterns of the protein, therefore an individual may not be allergic to other species of fish if they do not produce $\operatorname{IgE}$ to the exact same parvalbumin epitope [72]. Clinical cross-reactivity also does not frequently occur with shellfish and mollusks. The vast majority of crustaceanallergic patients are not allergic to mollusks [73].

Another misconception is that allergy to one tree nut means all nuts should be avoided. Recent studies have demonstrated that patients allergic to tree nuts are not 
necessarily allergic to all tree nuts [74, 75]. Although avoidance of all tree nuts could be due to risk of crosscontamination, there are multiple products available now manufactured in single tree nut allergen factories. Unfortunately, the responsibility to ensure these products are free of other allergens falls on the patient, because the labeling laws do not mandate labeling of specific tree nuts. It is important that a history of an adverse reaction to a tree nut be thoroughly investigated and SPT and $\operatorname{sgE}$ blood testing should be considered for other tree nuts in order to confirm whether there are other nut sensitivities. The utility of component resolved diagnostic testing has provided additional information to help the clinician determine whether an individual's sensitivity is secondary to a true allergy or cross-reactivity with tree pollen and provides information as to whether the patient could successfully undergo a tree nut oral challenge [76-81].

\section{Conclusions/summary}

IgE-mediated food allergies can cause gastrointestinal symptoms like pain, nausea, vomiting, and diarrhea when an offending food protein is ingested. The life-threatening nature of this disease has prompted deep understanding of the immunologic mechanisms driving the allergic state. Dendritic cells and T cells drive the production of Th2 helper cytokines to stimulate B cell generation of food-specific IgE when allergic sensitization occurs. Then, upon subsequent exposure to the food, a host of symptoms ensue. These can include mild cutaneous reactions or more severe reactions with more than one respiratory, gastrointestinal, cardiovascular, or neurological system involved. Diagnosis can be challenging with oral food challenge as the gold standard procedure which should be performed if the clinical history and food-specific IgE testing is not conclusive. The management of IgE-mediated food allergies includes prompt treatment of allergic reactions, strict food avoidance, and use of prevention strategies like early introduction of foods. In the future, it is likely immunotherapy will become useful in the management of IgE-mediated food allergy.

Funding This manuscript was funded internally.

\section{Compliance with Ethical Standards}

Conflicts of Interest Dr. Anvari and Dr. Davis have research contracts for clinical trials and research with ThermoFisher Scientific, Aimmune Therapeutics, Inc., and DBV Technologies, Inc.

Ethical Approval and Informed Consent No approvals or informed consents were obtained, as this manuscript does not contain primary research data.
Open Access This article is distributed under the terms of the Creative Commons Attribution 4.0 International License (http:// creativecommons.org/licenses/by/4.0/), which permits unrestricted use, distribution, and reproduction in any medium, provided you give appropriate credit to the original author(s) and the source, provide a link to the Creative Commons license, and indicate if changes were made.

\section{References}

1. Boyce JA, Assa'ad A, Burks AW, Jones SM, Sampson HA, Wood RA, Plaut M, Cooper SF, Fenton MJ, Arshad SH, Bahna SL, Beck LA, Byrd-Bredbenner C, Camargo CA Jr, Eichenfield L, Furuta GT, Hanifin JM, Jones C, Kraft M, Levy BD, Lieberman P, Luccioli S, KM MC, Schneider LC, Simon RA, Simons FE, Teach SJ, Yawn BP, Schwaninger JM (2011) Guidelines for the diagnosis and management of food allergy in the United States: summary of the NIAID-sponsored expert panel report. J Allergy Clin Immunol 126:1105-1118. https://doi.org/10.1016/j.jaci.2010.10.008

2. Sampson HA, Aceves S, Bock SA, James J, Jones S, Lang D, Nadeau K, Nowak-Wegrzyn A, Oppenheimer J, Perry TT, Randolph C, Sicherer SH, Simon RA, Vickery BP, Wood R, Joint Task Force on Practice Parameters, Bernstein D, BlessingMoore J, Khan D, Lang D, Nicklas R, Oppenheimer J, Portnoy J, Randolph C, Schuller D, Spector S, Tilles SA, Wallace D, Practice Parameter Workgroup, Sampson HA, Aceves S, Bock SA, James J, Jones S, Lang D, Nadeau K, Nowak-Wegrzyn A, Oppenheimer J, Perry TT, Randolph C, Sicherer SH, Simon RA, Vickery BP, Wood R (2014) Food allergy: a practice parameter update-2014. J Allergy Clin Immunol 134(5):1016-25.e43. https://doi.org/10.1016/j.jaci.2014.05.013

3. McDole JR, Wheeler LW, McDonald KG, Wang B, Konjufca V, Knoop KA, Newberry RD, Miller MJ (2012) Goblet cells deliver luminal antigen to CD103+ dendritic cells in the small intestine. Nature 483(7389):345-349

4. Mazzini E, Massimiliano L, Penna G, Rescigno M (2014) Oral tolerance can be established via gap junction transfer of fed antigens from $\mathrm{CX} 3 \mathrm{CR} 1^{+}$macrophages to $\mathrm{CD} 103^{+}$dendritic cells. Immunity 40(2):248-261

5. Coombes JL, Siddiqui KR, Arancibia-Cárcamo CV, Hall J, Sun CM, Belkaid Y, Powrie F (2007) A functionally specialized population of mucosal CD103+ DCs induces Foxp3+ regulatory T cells via a TGF-beta and retinoic acid-dependent mechanism. J Exp Med 204(8):1757-1764

6. Hadis U, Wahl B, Schulz O, Hardtke-Wolenski M, Schippers A, Wagner N, Müller W, Sparwasser T, Förster R, Pabst O (2011) Intestinal tolerance requires gut homing and expansion of FoxP3+ regulatory T cells in the lamina propria. Immunity 34(2):237-246

7. Paul WE, Zhu J (2010) How are T(H)2-type immune responses initiated and amplified? Nat Rev Immunol 10(4):225-235

8. Divekar R, Kita H (2015) Recent advances in epitheliumderived cytokines (IL-33, IL-25, and thymic stromal lymphopoietin) and allergic inflammation. Curr Opin Allergy Clin Immunol 15(1):98-103

9. Steinbach EC, Plevy SE (2014) The role of macrophages and dendritic cells in the initiation of inflammation in IBD. Inflamm Bowel Dis 20(1):166-175

10. Blázquez AB, Berin MC (2008) Gastrointestinal dendritic cells promote Th2 skewing via OX40L. J Immunol 180(7):4441-4450

11. Noval Rivas M, Burton OT, Oettgen HC, Chatila T (2016) IL-4 production by group 2 innate lymphoid cells promotes food allergy 
by blocking regulatory T-cell function. J Allergy Clin Immunol 138(3):801-811

12. Mjösberg J, Bernink J, Golebski K, Karrich JJ, Peters CP, Blom B, te Velde AA, Fokkens WJ, van Drunen CM, Spits H (2012) The transcription factor GATA3 is essential for the function of human type 2 innate lymphoid cells. Immunity 37(4):649-659

13. Saenz SA, Siracusa MC, Monticelli LA, Ziegler CG, Kim BS, Brestoff JR, Peterson LW, Wherry EJ, Goldrath AW, Bhandoola A, Artis D (2013) IL-25 simultaneously elicits distinct populations of innate lymphoid cells and multipotent progenitor type 2 (MPPtype2) cells. J Exp Med 210(9):1823-1837

14. Halim TY, Steer CA, Mathä L, Gold MJ, Martinez-Gonzalez I, McNagny KM, McKenzie AN, Takei F (2014) Group 2 innate lymphoid cells are critical for the initiation of adaptive T helper 2 cell-mediated allergic lung inflammation. Immunity 40(3):425-435

15. Bakdash G, Vogelpoel LT, van Capel TM, Kapsenberg ML, de Jong EC (2015) Retinoic acid primes human dendritic cells to induce gut-homing, IL-10-producing regulatory T cells. Mucosal Immunol 8(2):265-278

16. Evans TI, Reeves RK (2013) All-trans-retinoic acid imprints expression of the gut-homing marker $\alpha 4 \beta 7$ while suppressing lymph node homing of dendritic cells. Clin Vaccine Immunol 20(10):1642-1646

17. Sakaguchi S, Yamaguchi T, Nomura T, Ono M (2008) Regulatory T cells and immune tolerance. Cell 133(5):775-787

18. Sehra S, Yao W, Nguyen ET, Glosson-Byers NL, Akhtar N, Zhou B, Kaplan MH (2015) TH9 cells are required for tissue mast cell accumulation during allergic inflammation. J Allergy Clin Immunol 136(2):433-440

19. Sugimoto M, Kamemura N, Nagao M, Irahara M, Kagami S, Fujisawa T, Kido H (2016) Differential response in allergenspecific IgE, IgGs, and IgA levels for predicting outcome of oral immunotherapy. Pediatr Allergy Immunol 27(3):276-282

20. Meiler F, Klunker S, Zimmermann M, Akdis CA, Akdis M (2008 Nov) Distinct regulation of IgE, IgG4 and IgA by T regulatory cells and toll-like receptors. Allergy 63(11):1455-1463

21. Stone KD, Prussin C, Metcalfe DD (2010) IgE, mast cells, basophils, and eosinophils. J Allergy Clin Immunol 125(2 Suppl 2): S73-S80

22. Pereira PJ, Bergner A, Macedo-Riberiro S et al (1998) Human beta tryptase is a ring-like tetramer with active sites facing a central port. Nature 392(6673):306-311

23. Molinari JF, Scuri M, Moore WR, Clark J, Tanaka R, Abraham WM (1996) Inhaled tryptase causes bronchoconstriction in sheep via histamine release. Am J Respir Crit Care Med 154(3 pt 1):649-653

24. Ho MH, Wong WH, Chang C (2014) Clinical spectrum of food allergies: a comprehensive review. Clin Rev Allergy Immunol 46(3):225-240

25. Sampson HA, Muñoz-Furlong A, Campbell RL, Adkinson NF Jr, Bock SA, Branum A, Brown SG, Camargo CA Jr, Cydulka R, Galli SJ, Gidudu J, Gruchalla RS, Harlor AD Jr, Hepner DL, Lewis LM, Lieberman PL, Metcalfe DD, O'Connor R, Muraro A, Rudman A, Schmitt C, Scherrer D, Simons FE, Thomas S, Wood JP, Decker WW (2006) Second symposium on the definition and management of anaphylaxis: summary report - second National Institute of Allergy and Infectious Disease/Food Allergy and Anaphylaxis Network symposium. Ann Emerg Med 47(4):373-380

26. Sharma HP, Bansil S, Uygungil B (2015) Signs and symptoms of food allergy and food-induced anaphylaxis. Pediatr Clin N Am 62(6):1377-1392. https://doi.org/10.1016/j.pcl.2015.07.008

27. Gerbens LA, Prinsen CA, Chalmers JR, Drucker AM, von Kobyletzki LB, Limpens J, Nankervis H, Svensson Å, Terwee CB, Zhang J, Apfelbacher CJ, Spuls PI, Harmonising Outcome Measures for Eczema (HOME) Initiative (2017) Evaluation of the measurement properties of symptom measurement instruments for atopic eczema: a systematic review. Allergy 72:146-163. https:// doi.org/10.1111/all.12959

28. Cox LS, Sanchez-Borges M, Lockey RF (2017) World allergy organization systemic allergic reaction grading system: is a modification needed? J Allergy Clin Immunol Pract 5:58-62.e5. https://doi. org/10.1016/j.jaip.2016.11.009

29. Rudders SA, Banerji A, Clark S, Camargo CA Jr (2011) Agerelated differences in the clinical presentation of food-induced anaphylaxis. J Pediatr 158:326-328. https://doi.org/10.1016/j. jpeds.2010.10.017

30. Upton J, Nowak-Wegrzyn A (2018) The impact of baked egg and baked milk diets on IgE- and non-IgE-mediated allergy. Clin Rev Allergy Immunol. https://doi.org/10.1007/s12016-018-8669-0

31. Martin PE, Eckert JK, Koplin JJ, Lowe AJ, Gurrin LC, Dharmage SC, Vuillermin P, Tang MLK, Ponsonby AL, Matheson M, Hill DJ, Allen KJ, for the HealthNuts Study Investigators (2015) Which infants with eczema are at risk of food allergy? Results from a population-based cohort. Clin Exp Allergy 45:255-264

32. Bernstein IL, Li JT, Bernstein DI et al (2008) Allergy diagnostic testing: an updated practice parameter. Ann Allergy Asthma Immunol 100(Suppl 3):S1-S148

33. Sampson HA (1998) Comparative study of commercial food antigen extracts for the diagnosis of food hypersensitivity. J Allergy Clin Immunol 82:718-726

34. Peters RL, Gurrin LC, Allen KJ (2012) The predictive value of skin prick testing for challenge-proven food allergy: a systematic review. Pediatr Allergy Immunol 23(4):347-352

35. Sporik R, Hill DJ, Hosking CS (2000) Specificity of allergen skin testing in predicting positive open food challenges to milk, egg, and peanut in children. Clin Exp Allergy 30(11):1540-1546

36. Sampson HA (2001) Utility of food-specific IgE concentrations in predicting symptomatic food allergy. J Allergy Clin Immunol 107(5):891-896

37. Garcia-Ara C, Boyano-Martinez T, Diaz-Pena JM et al (2001) Specific IgE levels in the diagnosis of immediate hypersensitivity to cows' milk protein in the infant. J Allergy Clin Immunol 107(1): $185-190$

38. Klemans RJ, Otte D, Knol M et al (2013) The diagnostic value of specific IgE to Ara h2 to predict peanut allergy in children is comparable to a validated and updated diagnostic prediction. J Allergy Clin Immunol 131(1):157-163. https://doi.org/10. 1016/j.jaci.2012.08.010

39. Nowak-Wegrzyn A, Assa'ad AH, Bahna SL et al (2009) Work group report: oral food challenge testing. J Allergy Clin Immunol 123(6 Suppl):S365-S383

40. Grabenhenrich LB, Dölle S, Moneret-Vautrin A, Köhli A, Lange L, Spindler T, Ruëff F, Nemat K, Maris I, Roumpedaki E, Scherer K, Ott H, Reese T, Mustakov T, Lang R, Fernandez-Rivas M, Kowalski ML, Bilò MB, Hourihane JO, Papadopoulos NG, Beyer K, Muraro A, Worm M (2016) Anaphylaxis in children and adolescents: the European anaphylaxis registry. J Allergy Clin Immunol 137(4):1128-1137.e1. https://doi.org/10.1016/j.jaci.2015.11.015

41. Sicherer SH, Simons ER (2007) Self-injectable epinephrine for first-aid management of anaphylaxis. Pediatrics 119(3):638-646

42. Rueter K, Ta B, Bear N, Lucas M, Borland ML, Prescott SL (2018) Increased use of adrenaline in the management of childhood anaphylaxis over the last decade. J Allergy Clin Immunol Pract 6(5): $1545-1552$

43. Simons FE, Simons KJ (2011) Histamine and H1-antihistamines: celebrating a century of progress. J Allergy Clin Immunol 128(6): 1139-1150.e4. https://doi.org/10.1016/j.jaci.2011.09.005

44. Ruiz Oropeza A, Lassen A, Halken S, Bindslev-Jensen C, Mortz CG (2017) Anaphylaxis in an emergency care setting: a one year prospective study in children and adults. Scand J Trauma Resusc Emerg Med 25(1):111. https://doi.org/10.1186/ s13049-017-0402-0. 
45. Gupta R, Holdford D, Bilaver L, Dyer A, Holl JL, Meltzer D (2013) The economic impact of childhood allergy in the United States. JAMA Pediatr 167(11):1026-1031. https://doi.org/10.1001/ jamapediatrics.2013.2376

46. Berni Canani R, Leone L, D'Auria E, Riva E, Nocerino R, Ruotolo S, Terrin G, Cosenza L, Di Costanzo M, Passariello A, Coruzzo A, Agostoni C, Giovannini M, Troncone R (2014) The effects of dietary counseling on children with food allergy: a prospective, multicenter intervention study. J Acad Nutr Diet 114(9):1432-1439. https://doi.org/10.1016/j.jand.2014.03.018

47. Hefle SL, Furlong TJ, Niemann L, Lemon-Mule H, Sicherer S, Taylor SL (2007) Consumer attitudes and risks associated with packaged foods having advisory labeling regarding the presence of peanuts. J Allergy Clin Immunol 120(1):171-176

48. Marchisotto MJ, Harada L, Kamdar O, Smith BM, Waserman S, Sicherer S, Allen K, Muraro A, Taylor S, Gupta RS (2017) Food allergen labeling and purchasing habits in the United States and Canada. J Allergy Clin Immunol Pract 5(2):345-351.e2. https:// doi.org/10.1016/j.jaip.2016.09.020

49. Begen FM, Barnett J, Barber M, Payne R, Gowland MH, Lucas JS (2017) Parents' and caregivers' experiences and behaviours when eating out with children with a food hypersensitivity. BMC Public Health 18(1):38. https://doi.org/10.1186/s12889-017-4594-z.

50. Radke TJ, Brown LG, Hoover ER, Faw BV, Reimann D, Wong MR, Nicholas D, Barkley J, Ripley D (2016) Food allergy knowledge and attitudes of restaurant managers and staff: an EHS-net study. J Food Prot 79(9):1588-1598. https://doi.org/10.4315/ 0362-028X.JFP-16-085.

51. Bartnikas LM, Huffaker MF, Sheehan WJ, Kanchongkittiphon W, Petty CR, Leibowitz R, Hauptman M, Young MC, Phipatanakul W (2017) Impact of school peanut-free policies on epinephrine administration. J Allergy Clin Immunol 140(2):465-473. https://doi.org/ 10.1016/j.jaci.2017.01.040

52. Duncan SE, Annunziato RA (2018) Barriers to self-management behaviors in college students with food allergies. J Am Coll Heal. https://doi.org/10.1080/07448481.2018.1431898

53. Karam M, Scherzer R, Ogbogu PU, Green TD, Greenhawt M (2017) Food allergy prevalence, knowledge, and behavioral trends among college students-a 6-year comparison. J Allergy Clin Immunol Pract 5(2):504-506.e5. https://doi.org/ 10.1016/j.jaip.2016.11.035

54. Hobbs CB, Skinner AC, Burks AW, Vickery BP (2015) Food allergies affect growth in children. J Allergy Clin Immunol Pract 3(1): 133-4.e1

55. Christie L, Hine RJ, Parker JG, Burks W (2002) Food allergies in children affect nutrient intake and growth. J Am Diet Assoc 102(11):1648-1651

56. Sova C, Feuling MB, Baumler M, Gleason L, Tam JS, Zafra H, Goday PS (2013) Systematic review of nutrient intake and growth in children with multiple IgE-mediated food allergies. Nutr Clin Pract 28(6):669-675. https://doi.org/10.1177/0884533613505870

57. Du Toit G, Roberts G, Sayre PH, Bahnson HT, Radulovic S, Santos AF, Brough HA, Phippard D, Basting M, Feeney M, Turcanu V, Sever ML, Gomez Lorenzo M, Plaut M, Lack G, LEAP Study Team (2015) Randomized trial of peanut consumption in infants at risk for peanut allergy. N Engl J Med 372(9):803-813. https:// doi.org/10.1056/NEJMoa1414850

58. Du Toit G, Sayre PH, Roberts G, Sever ML, Lawson K, Bahnson HT, Brough HA, Santos AF, Harris KM, Radulovic S, Basting M, Turcanu V, Plaut M, Lack G, Immune Tolerance Network LEAPOn Study Team (2016) Effect of avoidance on peanut allergy after early peanut consumption. N Engl J Med 374(15):1435-1443. https://doi.org/10.1056/NEJMoa1514209

59. Pitt TJ, Becker AB, Chan-Yeung M, Chan ES, Watson WTA, Chooniedass R, Azad MB (2018) Reduced risk of peanut sensitization following exposure through breast-feeding and early peanut introduction. J Allergy Clin Immunol 141(2):620-625.e1. https:// doi.org/10.1016/j.jaci.2017.06.024

60. Fleischer DM, Sicherer S, Greenhawt M et al (2015) Consensus communication on early peanut introduction and the prevention of peanut allergyin high-risk infants. J Allergy Clin Immunol 136(2): 258-261

61. Anagnostou K, Islam S, King Y, Islam S, Deighton J, Ewan P (2014) Assessing the ef- ficacy of oral immunotherapy for the desensitisation of peanut allergy in children (STOP II): a phase 2 randomised controlled trial. Lancet 383:1297-1304

62. Jones SM, Sicherer SH, Burks AW, Leung DY, Lindblad RW, Dawson P, Henning AK, Berin MC, Chiang D, Vickery BP, Pesek RD, Cho CB, Davidson WF, Plaut M, Sampson HA, Wood RA, Consortium of Food Allergy Research (2017) Epicutaneous immunotherapy for the treatment of peanut allergy in children and young adults. J Allergy Clin Immunol 139(4):1242-1252.e9. https://doi.org/10.1016/j.jaci.2016.08.017

63. Sampson HA, Shreffler WG, Yang WH, Sussman GL, BrownWhitehorn TF, Nadeau KC, Cheema AS, Leonard SA, Pongracic JA, Sauvage-Delebarre C, Assa'ad AH, de Blay F, Bird JA, Tilles SA, Boralevi F, Bourrier T, Hébert J, Green TD, Gerth van Wijk R, Knulst AC, Kanny G, Schneider LC, Kowalski ML, Dupont C (2017) Effect of varying doses of Epicutaneous immunotherapy vs placebo on reaction to peanut protein exposure among patients with peanut sensitivity: a randomized clinical trial. JAMA 318(18): 1798-1809. https://doi.org/10.1001/jama.2017.16591

64. Narisety SD, Frischmeyer-Guerrerio PA, Keet CA, Gorelik M, Schroeder J, Hamilton RG, Wood RA (2015) A randomized, double-blind, placebo-controlled pilot study of sublingual versus oral immunotherapy for the treatment of peanut allergy. J Allergy Clin Immunol 135:1275-1282

65. Chapman JA, Bernstein IL, Lee RI, Oppenhemier J (2006) Food allergy. A practice parameter. Ann Allergy Asthma Immunol 96(3 suppl 2):S1-S68

66. Sicherer SH, Bock SA (2006) An expanding evidence base provides food for thought to avoid indigestion in managing difficult dilemmas in food allergy. J Allergy Clin Immunol 117:1419-1422

67. Perry TT, Matsui EC, Kay Conover-Walker M, Wood RA (2004) The relationship of allergen-specific IgE levels and oral food challenge outcomes. J Allergy Clin Immunol 114:144-149

68. Sicherer SH, Morrow EG, Sampson HA (2000) Dose-response in double-blind, placebo controlled oral food challenges in children with atopic dermatitis. J Allergy Clin Immunol 105:582-586

69. Roberts G, Lack G (2005) Diagnosing peanut allergy with skin prick and specific IgE testing. J Allergy Clin Immunol 115:1291-1296

70. Verstege A, Mehl A, Rolinck-Werninghaus C, Staden U, Nocon M, Beyer K, Niggemann B (2005) The predictive value of the skin prick test weal size for the outcome of oral food challenges. Clin Exp Allergy 35:1220-1226

71. Knight AK, Shreffler WG, Sampson HA et al (2006) Skin prick test to egg white provides additional diagnostic utility to serum egg white-specific IgE antibody concentration in children. J Allergy Clin Immunol 117:842-847

72. Lopata AL, O'Hehir RE, Lehrer SB (2010 Jun) Shellfish allergy. Clin Exp Allergy 40(6):850-858. https://doi.org/10.1111/j.13652222.2010.03513.x

73. Maskatia R, Chokshi N, Minard CG, Guffey D, Miller SB, Davis CM (2015) Pediatric risk factors of shrimp allergy. Allergy Asthma Proc 36(4):65-71

74. Couch C, Franxman T, Greenhawt M (2017) Characteristics of tree nut challenges in tree nut allergic and tree nut sensitized individuals. Ann Allergy Asthma Immunol 118:591-596

75. Elizur A, Appel M, Nachson L et al (2018) Nut Co-reactiviityacquiting knowledge for elimination recommendations (NUT CRACKER). Allergy 73:593-601 
76. Matricardi PM, Kleine-Tebbe J, Hoffmann HJ, Valenta R, Hilger C, Hofmaier S, Aalberse RC, Agache I, Asero R, Ballmer-Weber B, Barber D, Beyer K, Biedermann T, Bilò MB, Blank S, Bohle B, Bosshard PP, Breiteneder H, Brough HA, Caraballo L, Caubet JC, Crameri R, Davies JM, Douladiris N, Ebisawa M, EIgenmann PA, Fernandez-Rivas M, Ferreira F, Gadermaier G, Glatz M, Hamilton RG, Hawranek T, Hellings P, Hoffmann-Sommergruber K, Jakob T, Jappe U, Jutel M, Kamath SD, Knol EF, Korosec P, Kuehn A, Lack G, Lopata AL, Mäkelä M, Morisset M, Niederberger V, NowakWegrzyn AH, Papadopoulos NG, Pastorello EA, Pauli G, PlattsMills T, Posa D, Poulsen LK, Raulf M, Sastre J, Scala E, Schmid JM, Schmid-Grendelmeier P, van Hage M, van Ree R, Vieths S, Weber R, Wickman M, Muraro A, Ollert M (2016) EAACI molecular allergology user's guide. Pediatr Allergy Immunol 27(Suppl 23):1-250

77. Lange L, Lasota L, Finger A, Vlajnic D, Büsing S, Meister J, Broekaert I, Pfannenstiel C, Friedrichs F, Price M, Trendelenburg
V, Niggemann B, Beyer K (2017) Ana o 3-specific IgE is a good predictor for clinically relevant cashew allergy in children. Allergy 72:598-603

78. Sato S, Yamamoto M, Yanagida N et al (2017) Jug r 1 sensitization is important in walnut-allergic children and youth. J Allergy Clin Immunol Pract 5:1784.e1-1786.e1

79. Kattan JD, Sicherer SH, Sampson HA (2014) Clinical reactivity to hazelnut may be better identified by component testing than traditional testing methods. J Allergy Clin Immunol Pract 2:633.e1-634.e1

80. Masthoff LJ, Mattsson L, Zuidmeer-Jongejan L et al (2013) Sensitization to Cor a 9 and Cor a 14 is highly specific for a hazelnut allergy with objective symptoms in Dutch children and adults. $\mathrm{J}$ Allergy Clin Immunol 132:393-399

81. Eller E, Mortz CG, Bindslev-Jensen C (2016) Cor a 14 is the superior serological marker for hazelnut allergy in children, independent of concomitant peanut allergy. Allergy 71:556-562 